\title{
Faktor - Faktor Determinan Kurs Rupiah Terhadap Dollar Amerika
}

\author{
Utomo $^{1}$, Elys Fauziyah ${ }^{2 *}$
}

1,2 Prodi Agribisnis, Fakultas Pertanian, Universitas Trunojoyo Madura

\section{Informasi Artikel \\ Sejarah artikel: \\ Diterima November 2016 \\ Disetujui Maret 2017 \\ Dipublikasikan Maret 2017}

\section{Keywords:}

Exchange Rate;

Fluctuation;

Macroeconomic Variables

\begin{abstract}
A BS TRACT
Indonesia is a developing country that is often affected by fluctuations in foreign exchange rates, especially US Dollar. This condition is the effect of the government policies that implement the floating exchange rate system since August 14, 1977. The aims of this study are to know the development and to analyze the effect of macroeconomic variables on the Rupiah exchange rate against US Dollar in 2008-2014. The method which used in this study is descriptive statistics and multiple linear regression. The results of the study show that during 2008-2014, the variables of inflation, interest rate (BI rate) of Indonesia's balance of payments, and exports fluctuated, while the variable of $P D B$ tended to increase. Other results show that interest rates and gross domestic product have a positive effect on the exchange rate of Rupiah against US Dollar, whereas the inflation and exports have a negative effect. Meanwhile, Indonesia's balance of payments does not significantly affect the Rupiah against US Dollar.
\end{abstract}




\section{Pendahuluan}

Negara Indonesia merupakan negara berkembang yang sering terkena imbas dari fluktuasi kurs mata uang asing terutama mata uang dollar Amerika. Kondisi ini merupakan efek dari kebijakan pemerintah yang menerapkan sistem kurs mengambang sejak tanggal 14 Agustus 1997. Dengan berlakunya sistem kurs ini, mata uang asing sepenuhnya diserahkan atas permintaan dan penawaran terhadap mata uang yang bersangkutan di pasar internasional (Lipsey, dkk 1997).Seperti data yang dilansir dari Bank Indonesia perkembangan kurs rupiah terhadap dollar Amerika sejak tahun 2008 sampai dengan tahun 2014 mengalami fluktuasi. Efek dari adanya krisis global pada tahun 2008 membuat nilai tukar melemah menjadi Rp 10.950/USD. Kemudian pada tahun 2009 sampai dengan tahun 2012 kurs rupiah mengalami penurunan dan cenderung stabil, akan tetapi pada tahun 2013 sampai tahun 2014 kurs rupiah terhadap dollar Amerika meningkat lagi dengan posisi $\mathrm{Rp}$ 12.440,00/USD.

Ketidakstabilan kurs rupiah yang terjadi membuat pergerakan nilai rupiah sangat rentan bagi para pelaku ekonomi. Perubahan kurs dipengaruhi oleh banyak faktor salah satunya yaitu variabel makroekonomi yang bergejolak setiap waktu. Menurut Kuncoro (2013), tingkat suku bunga dalam dan luar negeri, jumlah uang beredar, dan tingkat inflasi merupakan faktor yang mempengaruhi kurs. Sedangkan hasil penelitian dari Sanya (2013), kurs dipengaruhi oleh PDB, tingkat inflasi, cadangan devisa, suku bunga uang, neraca pembayaran, dan kecenderungan untuk mengimpor. Sementara itu, penelitian dari Otuori (2013), kurs dipengaruhi oleh tingkat suku bunga, tingkat inflasi, hutang luar negeri, ekspor, dan impor.

Perubahan variabel makroekonomi akan mengakibatkan jumlah permintaaan ataupun jumlah penawaran kurs rupiah pada dollar Amerika. Variabel inflasi berpengaruh meningkatnya permintaan valuta asing. Menurut Puspitaningrum, dkk (2014) semakin tinggi tingkat inflasi di Indonesia maka akan mengakibatkan nilai tukar rupiah mengalami depresiasi terhadap dollar Amerika, karena semakin tinggi inflasi menyebabkan makin banyak kuota impor yang dilakukan. Begitu juga dengan variabel produk domestik bruto, semakin tinggi tingkat pertumbuhan pendapatan (relatif terhadap negara lain), makin besar kemungkinan untuk impor yang berakibat meningkatnya permintaan mata uang asing (Nopirin, 1999).

Pengaruh lain menunjukan bahwa, suku bunga mempengaruhi meningkatnya permintaan uang domestik. Jika suku bunga disuatu negara meningkat (relatif terhadap negara-negara lain), maka akan menarik para investor untuk menginvestasikan uangnya di negara tersebut. Kenaikan suku bunga membuat permintaan untuk uang domestik meningkat, sehingga mata uang domestik mengalami apresiasi (Patel dkk, 2014). Begitu juga dengan variabel ekspor yang menunjukan bahwa semakin meningkatnya volume ekspor maka akan meningkatkan penawaran mata uang asing di dalam negeri, sehingga akan menyebabkan mata uang asing terdepresiasi dan mata uang dalam negeri akan terapresiasi (Mankiw dkk, 2013). Begitu juga pendapat dari Genc dan Oksan (2014), variabel ekspor berpengaruh negatif terhadap kurs, yang artinya semakin tinggi ekspor akan menurunkan kurs valuta asing.

Sementara itu variabel neraca pembayaran dapat berpengaruh berupa apresiasi ataupun depresiasi pada kurs. Apabila neraca pembayaran berada pada posisi surplus maka mata uang domestik mengalami apresiasi, dan apabila neraca pembayaran akan mengalami defisit apabila pengeluaran luar negeri yang penduduk suatu negara melebihi jumlah penghasilan atau penerimaan yang diterima penduduk negara tersebut Rusniar (2009) dalam Muchlas dan Agus (2015).

Adanya berbagai variabel-variabel tersebut membuat kurs rupiah terhadap dollar Amerika menjadi rentan. Fluktuatif ini akan membuat sektor-sektor perdagangan dan 
sektor riil mengalami kebangkrutan, serta beban hutang luar negeri menjadi semakin besar. Dengan adanya fenomena tersebut menjadi dasar peneliti untuk menganalisis faktor-faktor apa saja yang mempengaruhi kurs rupiah terhadap dollar Amerika dalam kurun waktu tahun 2008-2014.

\section{Metode Penelitian}

Jenis data yang digunakan dalam penelitian ini adalah data sekunder yang diperoleh peneliti dari Bank Indonesia, Badan Pusat Statistik, berbagai buku, dan jurnal/skripsi yang relevan dengan penelitian ini. Data yang digunakan meliputi kurs rupiah terhadap dollar Amerika, inflasi, suku bunga Bank Indonesia, produk domestik bruto, neraca pembayaran, dan nilai ekspor dalam kurun waktu antara 2008-2014. Penelitian ini menggunakan dua metode analisis data yaitu metode deskriptif (kualitatif) dan regresi linear berganda. Metode deskriptif digunakan untuk menggambarkan kondisi masingmasing variabel penelitian dengan cara mendeskripsikan perkembangan masingmasing variabel. Sedangkan analisis regresi linear berganda digunakan untuk menganalisis pengaruh variabel independen terhadap variabel dependen berdasarkan asumsi-asumsi yang ditetapkan. Menurut (Sujarweni, 2014), asumsi yang harus dipenuhi terdiri dari normalitas, linieritas, autokorelasi, multikolonieritas, dan heterokidastisitas. Sedangkan persamaan regresi linear berganda yaitu sebagai berikut:

$\mathrm{Y}=\mathrm{a}+\mathrm{b}_{1} \mathrm{X}_{1}+\mathrm{b}_{2} \mathrm{X}_{2}+\mathrm{b}_{3} \mathrm{X}_{3}+\mathrm{b}_{4} \mathrm{X}_{4}+\mathrm{b}_{5} \mathrm{X}_{5}+\mathrm{e}$

Dimana, Y: Kurs rupiah terhadap dollar Amerika (diukur dalam satuan rupiah); a: Konstanta ; $\mathrm{X}_{1}$ : Tingkat inflasi (Peresentasi nilai inflasi Indonesia); $\mathrm{X}_{2}$ : Tingkat suku bunga (Persentase nilai suku bunga Bank Indonesia/BI rate); $\mathrm{X}_{3}$ : Produk Domestik Bruto (PDB harga konstan dalam triliun rupiah); $\mathrm{X}_{4}$ : Neraca Pembayaran Indonesia (diukur dalam satuan juta dollar Amerika); $\mathrm{X}_{5}$ : Nilai Ekspor (diukur dalam satuan juta dollar Amerika); $b_{1}-b_{5}$ : Koefisien Regresi; e : Variabel Penggangu.

\section{Hasil Dan Pembahasan \\ Deskriptif Faktor-Faktor Determinan Kurs Rupiah Terhadap USD}

Perkembangan kurs rupiah terhadap dollar Amerika semenjak diberlakukannya sistem mengambang oleh pemerintah Indonesia sering mengalami fluktuasi dan rupiah cenderung terdepresiasi. Hal ini karena permintaan dan penawaran mata uang dollar sepenuhnya diserahkan di pasar internasional. Begitu juga pada tahun 2008-2014, perkembangan kurs rupiah terhadap dollar Amerika mengalami fluktuasi. Faktor-faktor yang mempengarui kurs antara lain inflasi, suku bunga Bank Indonesia, produk domestik bruto, neraca pembayaran indonesia, dan ekspor. Hasil analisis deskriptif faktor-faktor tersebut dapat dilihat sebagai berikut:

\section{Deskripsi Perkembangan Inflasi}

Selama kurun waktu 2008-2014 laju inflasi di Indonesia mengalami fluktuasi. Adanya krisis global pada tahun 2008 membuat inflasi melambung tinggi sebesar $11.06 \%$, dan menurun tajam pada tahun 2009 efek dari semakin membaiknya perekonomian dunia. Tidak lancarnya pasokan bahan makanan dalam negeri membuat laju inflasi naik pada tahun 2010, dan cenderung menurun pada tahun 2011-2012. Penurunan ini tidak terlepas dari kebijakan moneter yang dilakukan oleh Bank Indonesia dan kebijakan pemerintah dengan menstabilkan harga, sehingga laju inflasi dapat tetap terjaga pada level yang rendah. Semakin meningkatnya harga minyak dunia membuat pemerintah menaikan harga BBM yang berakibat laju inflasi naik tajam tahun 2013. Begitu juga pada tahun 2014, laju inflasi masih tinggi karena adanya kebijakan pembatasan impor produk holtikul- 
tura dan akibat anomali cuaca yang meng- suku bunga pada posisi $6.50 \%$ dipandang gangu sektor pertanian dalam negeri. masih konsisten untuk mencapai

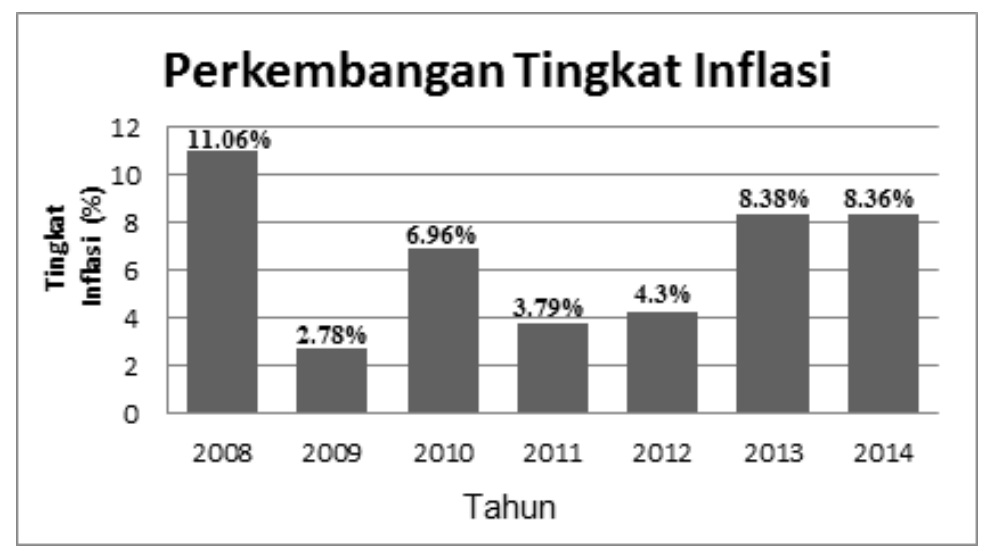

Sumber: Badan Pusat Statistik, 2015

Gambar 1

Grafik Perkembangan Inflasi Tahun 2008-2014

\section{Perkembangan Tingkat Suku Bunga BI}

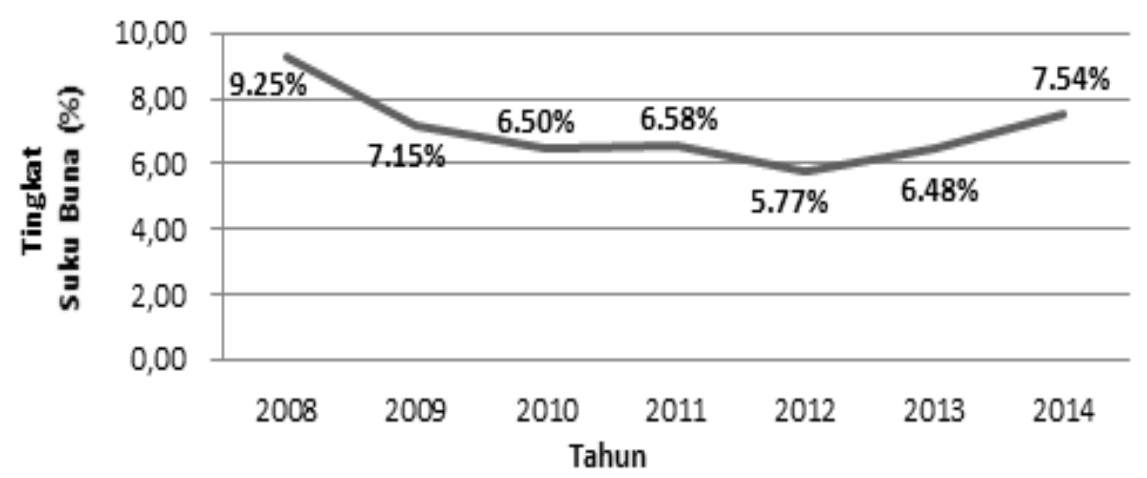

Sumber: Badan Pusat Statistik, 2015

Gambar 2

Grafik Perkembangan Tingkat Suku Bunga Bank Indonesia Tahun 2008 - 2014.

Deskriptif Perkembangan Suku Bunga

Berdasarkan hasil penelitian suku bunga Bank Indonesia selama tahun 2008-2014 mengalami fluktuasi, dengan tingkat suku bunga tertinggi pada tahun 2008 dan terendah pada tahun 2012. Suku bunga Bank Indonesia tertinggi terjadi pada tahun 2008, tingkat suku bunga tinggi diberlakukan oleh Bank Indonesia untuk menjaga pencapaian inflasi. Liquiditas pasar uang di dalam negeri yang semakin membaik membuat suku bunga diturunkan sepanjang tahun 2007. Level pencapaian sasaran inflasi pada tahun 2011-2012. Efek melambatnya perekonomian nasional membuat suku bunga ditrunkan pada tahun 2012, dan dinaikan lagi pada tahun 2013 sampai 2014 dengan tujuan untuk mengembalikan sasaran inflasi dan menjaga stabilitas perekonomian dalam negeri.

\section{Deskriptif Perkembangan Produk Do- mestik Bruto (Produksi)}

Berdasarkan penelitian menunjukkan bahwa sepanjang tahun 2008-2014 


\section{Perkembangan PDB Produksi}

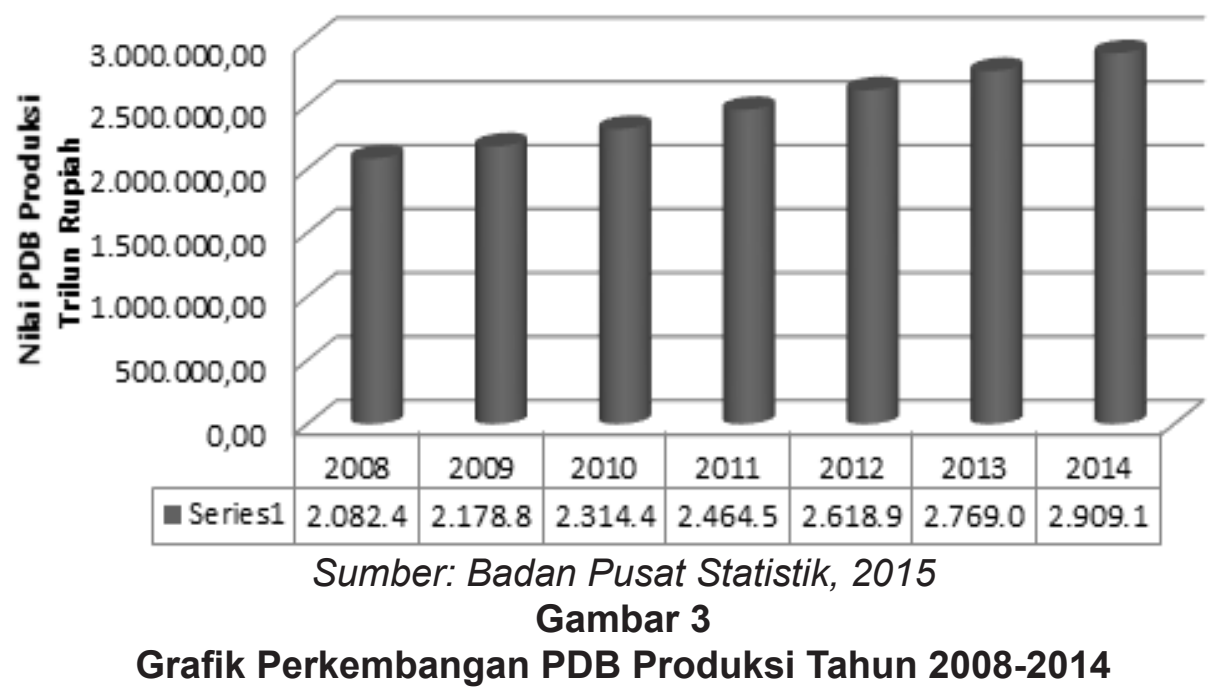

PDB produksi menunjukan peningkatan setiap tahunnya, dengan nilai rata-rata sebesar 2,476,785.4 miliar rupiah.

PDB tahun 2008 secara umum mencatat perkembangan yang cukup baik di tengah terjadinya gejolak eksternal. Pertumbuhan PDB secara keseluruhan tumbuh mencapai $6.1 \%$ pada 2008 atau sedikit lebih rendah dibandingkan dengan tahun sebelumnya sebesar $6.3 \%$, dan melambat juga sepanjang tahun 2009. Efek perekonomian global yang semakin membaik, PDB tahun 2010 tumbuh mencapai $6.1 \%$. Pertumbuhan ekonomi yang meningkat tersebut didukung oleh peran investasi dan ekspor yang meningkat. Meningkatnya investasi dan ekspor membuat PDB tumbuh sebesar $6.5 \%$, akan tetapi pada tahun 2012 perkembangan PDB mengalami penurunan akibat turunnya kinerja ekspor, hal ini karena efek dari kondisi perekonomian global yang tidak menentu. Kinerja PDB selama tahun 2013 sampai 2014 mengalami penurunan yang signifikan dan hanya mencatat sebesar $5.78 \%$ tahun 2013 dan $5.00 \%$ tahun 2014 . Penurunan ini akibat penuruan kinerja ekspor dari negara-negara emerging market yang sebelumnya sebagai pemasok ekspor utama dari Indonesia.

\section{Deskriptif Perkembangan Neraca Pem- bayaran Indonesia}

Berdasarkan hasil penelitian selama tahun 2008-2014 posisi neraca pembayaran mengalami perubahan yang bervariasi, dengan nilai rata-rata 8.700 Juta USD, nilai terendah -7.325 Juta USD, dan tertinggi 30.343 Juta USD. Efek perekonomian global yang memburuk membuat kinerja NPI mengalami tekanan yang cukup berat dan mencatat defisit sebesar 1.945 juta dollar Amerika. Membaiknya perekonomian negara maju juga berakibat membaiknya kinerja eskpor dan harga komoditas ekspor yang berimplikasi NPI mengalami surplus sepanjang tahun 2009-2010. Melambatnya perekonomian global membuat NPI turun tajam pada tahun 2011-2012 dan sempat mengalami defist pada tahun 2013. Adanya kebijakan Bank Indonesia serta dukungan penuh oleh pemerintah pada tahun 2014 berhasil menekan defisist neraca pembayaran kearah yang lebih sehat dan berhasil mencatat surplus pada tahun 2014.

\section{Deskriptif Perkembangan Ekspor}

Berdasarkan hasil penelitian dapat di ketahui bahwa nilai ekspor sepanjang 


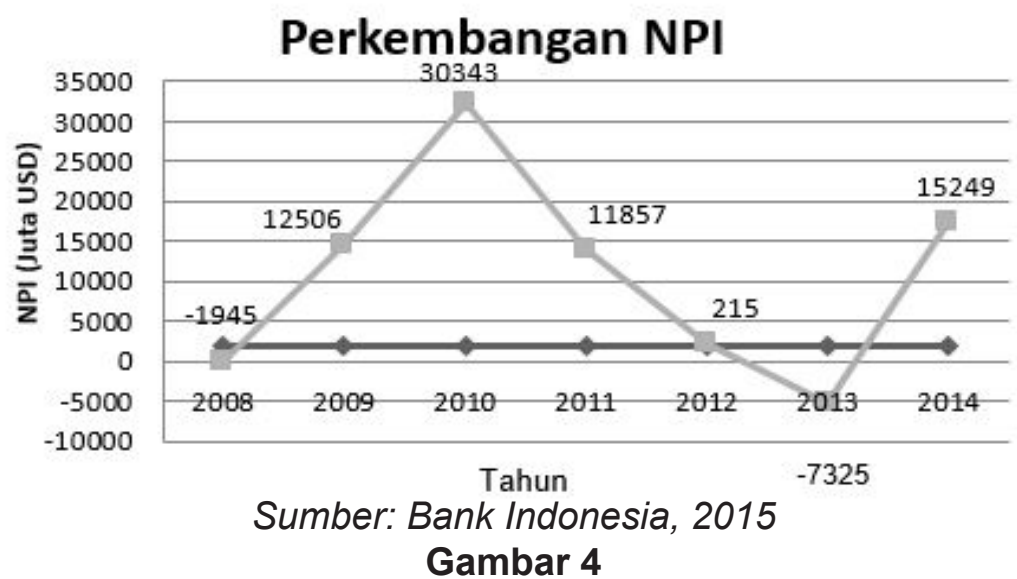

Grafik Perkembangan NPI Tahun 2008 - 2014

tahun 2008-2014 mengalami naik turun yang bervariasi. Nilai ekspor tertinggi kenaikan membuat kinerja eskpor naik pada tahun 2011 dengan nilai 203,496.6 tajam pada tahun 2011, dan menurun miliar USD, dan terendah pada tahun sepanjang tahun 2012-2014. Tahun 2012 2009 sebesar 116,510 miliar USD den- Penurunan kinerja ekspor diakibatkan gan rata-rata sebesar 166,195.80 miliar menurunnya produk manufaktur dan perUSD. Walaupun pada tahun 2008 terjadi tambangan maupun minyak akibat perkrisis global, kinerja ekspor masih cukup mintaan dunia yang melemah serta harga bagus jika dibandingkan dengan tahun ekspor yang turun. Akibat melambatnya sebelumnya. Akan tetapi pada tahun 2009 perekomian global dan masih menurunnya kinerja eskpor menurun tajam akibat me- harga komoditas global membuat kinerja lemahnya permintaan dari sisi eksternal. ekspor menurun pada 2013. Selama tahun Kemudian pada tahun 2010 nilai ekspor kinerja ekspor masih menurun akibat memeningkat, naiknya ekspor ini terjadi dise- lemahnya ekspor komoditas SDA dan ini luruh sektor baik migas ataupun nonmigas. memberikan tekanan kinerja ekspor nonSemakin baiknya kinerja ekspor ini migas. diakibatkan seiring kenaikan permintaan dunia dan tingginya harga di pasar internasional. Semakin membaiknya harga komoditas

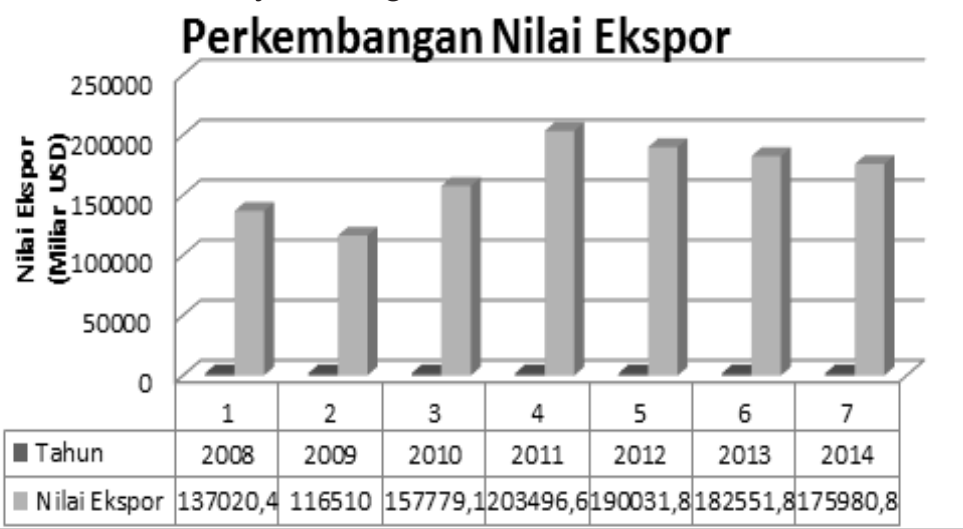

Sumber: Badan Pusat Statistik, 2015

Gambar 5

Grafik Perkembangan Nilai Ekspor Tahun 2008-2014 
Faktor-Faktor Yang Mempengaruhi Kurs Rupiah Terhadap Dollar Amerika Terdapat lima faktor yang dimasukan dalam model regresi linear berganda dan diduga berpengaruh pada kurs rupiah terhadap dollar Amerika yaitu inflasi, suku bunga, produk domestik bruto, neraca pembayaran Indonesia, dan nilai ekspor. Hasil analisis faktor-faktor yang mempengaruhi kurs rupiah terhadap dollar Amerika pada tahun 2008-2014 disajikan di Tabel berikut, dan data yang digunakan tersebut telah memenuhi asumsi klasik. parsial dapat dijelaskan sebagai berikut:

\section{Variabel Inflasi}

Berdasarkan hasil analisis nilai koefisien variabel inflasi pada analisis regresi memiliki tanda negatif sebesar (-)164.475 dan nilai thitung sebesar 2.477, hal ini dapat diartikan bahwa nilai thitung lebih besar dari nilai tabel 2.073. Sehingga dapat disimpulkan bahwa inflasi berpengaruh signifikan pada kurs rupiah terhadap dollar Amerika. Nilai koefisien sebesar (-)164.475 menunjukkan

Tabel 1

Hasil Uji Regresi Berganda

\begin{tabular}{lcccc}
\hline \multicolumn{1}{c}{ Variabel } & Koefisien & Standar Error & t Hitung & Sig \\
\hline Constan & 232.102 & 1148.524 & 0.202 & 0.842 \\
Inflasi & -164.475 & 66.390 & -2.477 & $0.021^{*}$ \\
Suku Bunga & 552.500 & 97.852 & 5.646 & $0.000^{*}$ \\
NPI & $8.559 \mathrm{E}-6$ & 0.018 & 0.000 & 1.000 \\
Ekspor & -103 & 0.015 & -7.007 & $0.000^{*}$ \\
PDB & 0.017 & 0.001 & 11.839 & $0.000^{*}$ \\
\hline Adjusted R Square & \multicolumn{5}{c}{} \\
F-Hitung & 0.868 & \\
Sig & 36.573 & & \\
\hline
\end{tabular}

Sumber: Data Sekunder Diolah, 2015

Ket : Tanda * menunjukkan signifikan pada a $5 \%$

Berdasarkan hasil analisis diketahui nilai Adjusted $R$ Square sebesar 0.868 $(86.8 \%)$, artinya bahwa variabel inflasi, suku bunga $\mathrm{BI}, \mathrm{PDB}$, dan ekspor mampu mempengaruhi nilai tukar sebesar $86.9 \%$, sedangkan sisanya $13.2 \%$ dipengaruhi oleh variabel lain yang tidak dimasukan dalam model regresi. Variabel lain tersebut seperti jumlah uang beredar, nilai impor, harga minyak dunia, kondisi politik negara, kondisi psikologis, dan kondisi cita rasa masyarakat. Sedangkan hasil pengujian koefisien secara simultan dapat dilihat dari uji F. Nilai Fhitung sebesar 36.57 sedangakan Ftabel 2.66, yang berarti Fhitung > Ftabel. Hal ini dapat disimpulkan bahwa variabel inflasi, suku bunga BI, PDB, dan ekspor secara bersama-sama berpengaruh signifikan terhadap nilai tukar rupiah terhadap dollar Amerika. Hasil pengujian koefisien secara bahwa kenaikan inflasi sebesar $1 \%$ dapat menurunkan kurs Rp/USD sebesar Rp 164.475, atau rupiah terapresiasi.

Pada umumnya ketika inflasi naik maka harga-harga di pasar domestik cenderung naik, sehingga ada kecenderungan untuk menambah impor dengan anggapan bahwa inflasi di negara lain lebih rendah. Akan tetapi dalam periode penelitian, tingginya inflasi tidak hanya terjadi di Indonesia namun diikuti oleh negaranegara lain. Selain itu kondisi inflasi dunia jika dibandingkan dengan inflasi Indonesia nilainya tidak jauh berbeda. Tingginya tingkat inflasi Indonesia juga terjadi pada inflasi dunia, hal ini karena selama tahun penelitian terjadi ketidakpastian perekonomian di pasar internasional. Hasil analisis dengan menggunakan uji t beda ratarata menunjukan bahwa tidak terdapat 
perbedaan antara inflasi dunia dengan inflasi Indonesia, atau dengan kata lain bahwa inflasi dunia sama dengan inflasi Indonesia. Hal ini menunjukkan harga barang atau jasa di pasar internasional juga tergolong tinggi, sehingga menurunkan daya beli masyarakat terhadap produk impor. Dengan menurunnya daya beli masyarakat akan produk impor maka secara tidak langsung akan mengurangi kuota impor, sehingga permintaan akan uang dollar akan menurun dan membuat rupiah terapresiasi.

Penelitian ini sejalan dengan penelitian yang dilakukan oleh Safitri dkk (2014), yang menyatakan bahwa variabel inflasi berpengaruh signifikan dengan arah negatif terhadap kurs. Tingkat inflasi memiliki koefisien negatif, yang berarti pertumbuhan tingkat inflasi berbanding terbalik dengan perubahan kurs. Sedangkan penelitian yang dilakukan oleh Muhammadinah (2011), variabel inflasi berpengaruh signifikan dengan arah negatif. Nilai koefisien regresi variabel tingkat inflasi yang diperoleh sebesar (-)135.630 menunjukkan bahwa apabila tingkat inflasi meningkat sebesar satu digit, maka nilai tukar rupiah akan meningkat sebesar 135.630 per dollar Amerika.

\section{Variabel Suku Bunga}

Berdasarkan hasil analisis nilai koefisien variabel suku bunga pada analisis regresi memiliki tanda positif yaitu sebesar 552.500 dan nilai thitung sebesar 5.646, hal ini dapat diartikan bahwa nilai thitung lebih besar dari nilai ttabel.Sehingga dapat disimpulkan bahwa suku bunga berpengaruh signifikan pada kurs rupiah terhadap dollar Amerika. Nilai koefisien sebesar 552.500 menunjukkan bahwa kenaikan suku bunga sebesar $1 \%$ dapat menaikan kurs rupiah terhadap dollar Amerika sebesar Rp 552.500 atau rupiah mengalami depresiasi.

Suku bunga merupakan salah satu kebijakan moneter dari Bank Indonesia yang dilakukan dengan cara me- naikan atau menurunkan tingkat suku bunga. Bila suku bunga dalam negeri relatif lebih tinggi dari pada negara lain ada kecenderungan menyimpan uang di Indonesia lebih menguntungkan. Dengan semakin tingginya suku bunga diharapkan menarik modal asing masuk sehingga jumlah penawaran uang asing bertambah yang berimplikasi uang asing terdepresiasi yang akan direspon oleh uang domestik akan mengalami apresiasi.

Hasil penelitian menunjukan kenaikan suku bunga tidak membuat kurs rupiah terapresiasi. Kenaikan suku bunga yang yang ditetapkan oleh Bank Indonesia tidak memberikan jaminan nilai tukar mata uang rupiah menguat dan aliran modal asing masuk ke Indonesia semakin meningkat. Kondisi ini disebabkan sepanjang tahun penelitian perekonomian Indonesia mengalami fluktuasi. Selain kondisi perekonomian, kondisi politik dan keamanan juga berakibat pada ketertarikan investor asing untuk menanamkan investasi di Indonesia. Dengan adanya hal tersebut ini membuat investor asing ataupun domestik lebih memilih menanamkan modal di negara lain yang kondisi ekonominya lebih stabil. Dengan larinya modal ke luar negeri ini mengakibatkan permintaan mata uang asing meningkat, sehingga akan mengakibatkan mata uang domestik terdepresiasi.

Penelitian ini sejalan dengan yang dilakukan oleh Muchlas dan Agus (2015), variabel suku bunga berpengaruh positif terhadap kurs rupiah atas dollar Amerika. Artinya setiap kenaikan tingkat suku bunga bank di Indonesia akan meningkatkan pergerakan kurs rupiah terhadap dolar Amerika. Begitu juga penelitian dari Stenly (2010), suku bunga SBI (Sertifikat Bank Indonesia) berpengaruh signifikan terhadap kurs rupiah atas dollar Amerika dengan arah positif.

\section{Variabel Produk Domestik Bruto}

Berdasarkan hasil analisis nilai koefisien variabel PDB pada analisis re- 
gresi memiliki tanda positif yaitu sebesar 0.017 dan nilai thitung sebesar 11.839, hal ini dapat diartikan bahwa nilai thitung lebih besar dari nilai ttabel. Sehingga dapat disimpulkan bahwa PDB berpengaruh signifikan pada kurs rupiah terhadap dollar Amerika. Nilai koefisien sebesar 0.017 menunjukkan bahwa kenaikan PDB sebesar Rp 1 miliar dapat menaikan kurs rupiah terhadap dollar Amerika sebesar Rp 0.017 atau rupiah terdepresiasi.

Produk Domestik Bruto merupakan jumlah nilai barang dan jasa yang dihasilkan oleh berbagai unit produksi pada wilayah suatu negara dalam jangka waktu tertentu (biasanya dalam satu tahun). PDB ini mengukur semua pendapatan barang dan jasa yang bersifat final, yaitu semua produk barang dan jasa dalam sistem perekonomian selama setahun dalam suatu negara. Selama periode penelitian PDB Indonesia mengalami tren yang meningkat setiap tahunnya. Meningkatnya PDB ini menunjukan daya beli masyarakat meningkat. Peningkatan daya beli ini akan meningkatkan harga-harga di pasar domestik menjadi mahal, sehingga ada kecenderungan melakukan impor.

Hal ini sesuai dengan pendekatan yang dilakukan oleh Keynes, bahwa peningkatan pendapatan akan meningkatkan impor. Begitu juga pendapat dari Nopirin (1999), makin tinggi tingkat pertumbuhan pendapatan (relatif terhadap negara lain), makin besar kemungkinan untuk impor. Dengan adanya impor tersebut mengakibatkan permintaan uang asing cenderung meningkat, sehingga harga mata uang asing (dollar Amerika) akan mahal dan mata uang rupiah mengalami depresiasi.

Penelitian ini searah dengan penelitian yang dilakukan oleh Parwanti (2011), nilai koefisien pendapatan Indonesia diperoleh -0,201572 artinya setiap kenaikan pendapatan Indonesia sebesar 1\% akan mendorong kurs rupiah turun dan mengalami depresiasi. Begitu juga pene- litian dari Pratiwi dan Purbayu (2012) menunjukan variabel PDB berpengaruh secara signifikan pada kurs rupiah terhadap dollar Amerika dengan arah negatif.

Variabel Neraca Pembayaran Indonesia

Berdasarkan hasil penelitian dapat diketahui nilai thitung sebesar 0.000 yang berarti lebih kecil dari ttabel. Dari hasil tersebut dapat disimpulkan bahwa variabel NPI tidak berpengaruh secara signifikan terhadap kurs rupiah terhadap dollar Amerika dalam kurun waktu 2008-2014. Hasil menunjukan apabila ada peningkatan atau penurunan neraca pembayaran Indonesia tidak mempengaruhi pergerakan kurs rupiah terhadap dollar Amerika.

Variabel NPI yang dipengarui oleh aliran dana impor dan ekspor atau jasa serta transaksi internasional tidak mempengarui signifikan rupiah terhadap dollar Amerika. Jika dilihat dari kinerja NPI selama tahun 2008-2014 mengalami fluktuasi. Dengan adanya fluktuasi NPI tersebut maka aliran dana yang masuk dan aliran dana yang keluar akan membentuk posisi ekuilibrium atau keseimbangan. Dengan adanya keseimbangan tersebut akan berakibat tidak berpengaruhnya kurs rupiah terhadap dollar Amerika.

Penelitian ini sejalan dengan penelitian yang dilakukan oleh Oktavia dkk. (2013), yang menunjukan neraca perdagangan secara parsial tidak memiliki pengaruh yang signifikan dan negatif terhadap kurs di Indonesia. Begitu juga penelitian yang dilakukan oleh Atmadja (2002), bahwa variabel nereca pembayaran Indonesia atau BOP tidak mampu memberikan pengaruh yang signifikan pada perubahan nilai tukar rupiah terhadap dolar Amerika. Sementara itu, penelitian ini berbeda dari penelitian yang dilakukan oleh Machpudin (2013) maupun Muchlas dan Agus (2015), yang menunjukan bahwa BOP mempengaruhi perubahan pergerakan kurs rupiah terhadap dollar Amerika, dengan pengaruh negatif, 
artinya setiap kenaikan BOP akan menurunkan pergerakan rupiah terhadap dollar Amerika.

\section{Variabel Ekspor}

Berdasarkan hasil analisis dapat diketahui nilai koefisien variabel ekspor pada analisis regresi memiliki tanda negatif yaitu sebesar (-)103 dan nilai thitung sebesar 7.007, hal ini dapat diartikan bahwa nilai thitung lebih besar dari nilai ttabel. Sehingga dapat disimpulkan bahwa ekspor berpengaruh secara signifikan pada kurs rupiah terhadap dollar Amerika. Nilai koefisien sebesar -103 menunjukkan bahwa kenaikan ekpor sebesar 1 juta USD dapat menurunkan kurs Rp/USD sebesar Rp 103 atau rupiah terapresiasi.

Ekspor merupakan kegiatan menjual barang dan jasa ke luar negeri. Selama tahun 2004-2014 nilai ekspor di Indonesia mengalami fluktuasi. Kondisi ini disebabkan oleh kondisi perekonomian dunia yang mengalami pasang surut. Dampak ekonomi dunia terhadap ekspor adalah positif. Menurut wild (2008) dalam Ratana dkk.,(2012). Ketika ekonomi dunia dalam keadaan membaik maka dunia dapat mengkonsumsi lebih banyak barang. Dalam Keadaan ini akan memicu peningkatan jumlah ekspor ke negara-negara yang memiliki ekonomi membaik tersebut.

Kegiatan ekspor mempunyai pengaruh yang besar terhadap kurs rupiah terhadap dollar Amerika. Kegiatan ekspor akan mengakibatkan jumlah penawaran uang asing dari para eksportir di dalam negeri bertambah. Sehingga akan mengakibatkan kelebihan uang asing di dalam negeri yang pada akhirnya menurunkan nilai mata uang asing (dollar Amerika). Dengan menurunnya nilai mata uang asing tersebut akan direspon oleh mata uang domestik menguat atau apresiasi.

Penelitian ini sama dengan penelitian yang dilakukan oleh Djulius dan Yudi (2014), yang menunjukan bahwa variabel ekspor berpengaruh nyata terhadap kurs rupiah terhadap dollar Amerika dengan arah positif. Hal ini menunjukan bahwa kenaikan ekspor justru akan menaikan kurs rupiah terhadap dollar Amerika. Begitu juga penelitian dari Yudha dan Syamsul (2009), variabel ekspor berpengaruh signifikan pada kurs rupiah terhadap dollar Amerika dengan arah negatif.

\section{Penutup}

Berdasarkan hasil penelitian yang dilakukan dapat disimpulkan bahwa 1) selama tahun 2008-2014 variabel inflasi, suku bunga ( $\mathrm{BI}$ rate), neraca pembayaran Indonesia, dan ekspor mengalami penurunan, sedangkan variabel PDB mengalami peningkatan. 2) Hasil pengujian dengan regresi linear berganda menunjukan bahwa variabel suku bunga dan produk domestik bruto berpengaruh signifikan dengan arah positif pada kurs rupiah terhadap dollar Amerika pada tahun 2008-2014. Sedangkan variabel inflasi dan ekspor berpengaruh signifikan dengan arah negatif. Hasil lain menunjukan variabel neraca pembayaran Indonesia tidak berpengaruh nyata terhadap kurs rupiah terhadap dollar Amerika.

Berdasarkan hasil analisis dapat direkomendasikan kebijakan yang dapat digunakan untuk menjaga kestabilan kurs rupiah:1) Stabilitas laju inflasi tetap rendah perlu dipertahankan dengan cara menjaga stabilitas harga-harga di pasar. Dengan inflasi yang rendah dapat meminimalkan kuota impor, dengan rendahnya impor akan mengurangi jumlah permintaan mata uang dollar Amerika. 2) Suku bunga Bank Indonesia (BI Rate) perlu ditingkatkan supaya dapat menarik para investor asing untuk menanamkan modal di Indonesia. Dengan adanya investasi dari asing diharapkan akan menambah jumlah penawaran mata uang dollar Amerika. 3) Lebih meningkatkan ekspor, karena dengan adanya eskpor dapat menambah cadangan devisa mata uang asing 
(dollar Amerika) di Indonesia, sehingga mengakibatkan rupiah terapresiasi. 4) Tren peningkatan produk domestik bruto perlu dijaga supaya dapat mempengaruhi minat investor asing untuk menanamkan modal di Indonesia.

\section{Daftar Pustaka}

Atmadja, A.S. 2002. Analisa Pergerakan Nilai Tukar Rupiah Terhadap Dolar Amerika Setelah Diterapkannya Kebijakan Sistem Nilai Tukar Mengambang Bebas Di Indonesia. Jurnal Akuntansi \& Keuangan 4(1): 69-78.

Badan Pusat Statistik (BPS). 2015. Berita Resmi Statistik No. 85/09/Th. XVIII. BPS. Jakarta.

Badan Pusat Statistik (BPS). Indikator Ekonomi, Buletin Statistik Bulanan Berbagai. BPS. Jakarta.

Badan Pusat Statistik. Produk Domestik Bruto Indonesia Triwulanan Berbagai. BPS. Jakarta.

Bank Indonesia. 2015. Kurs Transaksi Bank Indonesia. Bank Indonesia. Jakarta.

Bank Indonesia. Laporan Perekonomian Indonesia Berbagai Edisi. Bank Indonesia. Jakarta.

Djulius. H. dan Yudi. N. Keseimbangan Jangka Pendek dan Jangka Panjang Nilai Tukar Rupiah Terhadap Dollar Amerika. Trikonomika. 13(1): 13-20.

Genc, E. G, dan Oksan. K. A. The Effect Of Exchange Rates On Exports And Imports Of Emerging Countries. European Scientific Journal. 10(13):128-141.

Kuncoro, M. 2013. Mudah Memahami dan Menganalisis Indikator Ekonomi. UPP STIMKAS YKPN. Yogyakarta.

Lipsey., R.G. etc. 1997. Pengantar Makroekonomi. Edisi Kesepuluh. Diterjemahkan oleh: Agus Maulana. Erlanga. Jakarta.
Machpudin, A. 2013. Analisis Pengaruh Neraca Pembayaran Terhadap Nilai Tukar Rupiah (The Analysis Of Balance Payment Influence On Rupiah's Exchange Rate). Jurnal Dinamika Manajemen 1(3): 225-238.

Mankiw, N.G. etc. 2013. Pengantar Ekonomi Makro. Salemba Empat. Jakarta.

Muchlas, Z. dan Agus R.A. 2015. FaktorFaktor Yang Mempengaruhi Kurs Rupiah Terhadap Dollar Amerika Pasca Krisis (2000-2010). Jurnal JIBEKA 9(1): 76-86.

Muhammadinah. 2011. Pengaruh Tingkat Suku Bunga Bank Indonesia Dan Tingkat Inflasi Terhadap Nilai Tukar Rupiah Atas Dolar Amerika. Jurnal Ekonomi dan Informasi Akuntansi (Jenius)1(2): 118-130.

Nopirin. 1999. Ekonomi Internasional. Edisi Ketiga. BPFE. Yogyakarta.

Oktavia, A.L. etc. Analisis Kurs Dan Money Supply Di Indonesia. Jurnal Kajian Ekonomi 1(2): 149-165.

Otuori, O. H. Influence Of Exchange Rate Determinants On The Perfonmance Of Commercial Banks In Kenya. European Journal of Management Sciences and Economics. 1: 86-98.

Parwanti, N. 2011. Determinan Nilai Tukar Rupiah Terhadap Dollar Amerika Serikat (Dengan Menggunakan Monetary Approach) Periode 1990.1 - 2010.4, Skripsi. Progam Sarjana. Universitas Negeri Semarang. Semarang.

Pratiwi, T.E. dan Purbayu, B.S. 2012. Analisis Perilaku Kurs Rupiah (IDR) Terhadap Dollar Amerika (Usd) Pada Sistem Kurs Mengambang Bebas Di Indonesia Periode 1997.3 - 2011.4 (Aplikasi Pendekatan Keynesian Sticky Price Model). Diponegoro Journal Of Economics I(1): 1-13. 
Puspitaningrum, R. etc. 2014. Pengaruh Tingkat Inflasi, Tingkat Suku Bunga SBI, Dan Pertumbuhan Ekonomi Terhadap Kurs Rupiah Studi Pada Bank Indonesia Periode Tahun 2003-2012. Jurnal Administrasi Bisnis (JAB) 8(1): 1-9.

Ratana, D.S. etc. 2012. Dampak Perubahan Nilai Tukar Mata Uang Terhadap Ekspor Indonesia. Jurnal Manajemen \& Agribisnis 9(3):154-162.

Safitri, R. etc 2014. Analisis Aspek Fundamental Dan Psikologis Terhadap Perubahan Kurs Valas Di Indonesia Periode 2004 - 2012. Jurnal Ekonomi 22(3): 71-87.

Sanya, O. 2013. The Causative Factors In Exchange Rate Behaviour And Its Impact On Growth Of Nigerian Economy. European Scientific Journal 9(7): 288-299.

Stenly, F. Pengaruh Tingkat Suku Bunga Sertfikat Bank Indonesia Terhadap Perubahan Nilai Tukar (Kurs) Rupiah Atas Dolar Amerika: GrangerCausalitas Test. Jurnal Manajemen Teori dan Terapan (1): 42-55.

Sujarweni, V.W. SPSS Untuk Penelitian. Pustaka Baru Press. Yogyakarta.

Yudha, A. L. dan Syamsul. H. Analisis Pengaruh Tingkat Suku Bunga SBI dan Volume Ekspor Impor Terhadap Nilai Tukar Rupiah. Jurnal Ekonomi Pembangunan. 7(1): 47-62. 